\title{
Long-term feeding with high plant protein based diets in gilthead seabream (Sparus aurata, L.) leads to changes in the inflammatory and immune related gene expression at intestinal level
}

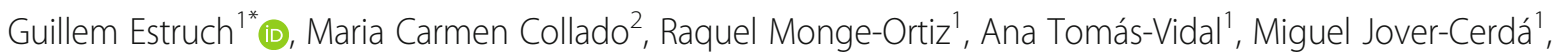 \\ David S Peñaranda', Gaspar Pérez Martínez ${ }^{2}$ and Silvia Martínez-Llorens ${ }^{1}$
}

\begin{abstract}
Background: In order to ensure sustainability of aquaculture production of carnivourous fish species such as the gilthead seabream (Sparus aurata, L.), the impact of the inclusion of alternative protein sources to fishmeal, including plants, has been assessed. With the aim of evaluating long-term effects of vegetable diets on growth and intestinal status of the on-growing gilthead seabream (initial weight $=129 \mathrm{~g}$ ), three experimental diets were tested: a strict plant protein-based diet (VM), a fishmeal based diet (FM) and a plant protein-based diet with 15\% of marine ingredients (squid and krill meal) alternative to fishmeal (VM+). Intestines were sampled after 154 days. Besides studying growth parameters and survival, the gene expression related to inflammatory response, immune system, epithelia integrity and digestive process was analysed in the foregut and hindgut sections, as well as different histological parameters in the foregut.

Results: There were no differences in growth performance $(p=0.2703)$ and feed utilization $(p=0.1536)$, although a greater fish mortality was recorded in the VM group $(p=0.0141)$. In addition, this group reported a lower expression in genes related to pro-inflammatory response, as Interleukine-1 $\beta$ (il $1 \beta, p=0.0415$ ), Interleukine-6 (il6, $p=0.0347$ ) and cyclooxigenase-2 (cox2, $p=0.0014$ ), immune-related genes as immunoglobulin M (igm, $p=0.0002$ ) or bacterial defence genes as alkaline phosphatase $(a / p, p=0.0069)$. In contrast, the $\mathrm{VM}+$ group yielded similar survival rate to FM $(p=0.0141)$ and the gene expression patterns indicated a greater induction of the inflammatory and immune markers (i/1 $\beta$, cox2 and igm). However, major histological changes in gut were not detected.

Conclusions: Using plants as the unique source of protein on a long term basis, replacing fishmeal in aqua feeds for gilthead seabream, may have been the reason of a decrease in the level of different pro-inflammatory mediators (il1 $\beta$, il6 and cox2) and immune-related molecules (igm and alp), which reflects a possible lack of local immune response at the intestinal mucosa, explaining the higher mortality observed. Krill and squid meal inclusion in vegetable diets, even at low concentrations, provided an improvement in nutrition and survival parameters compared to strictly plant protein based diets as VM, maybe explained by the maintenance of an effective immune response throughout the assay.
\end{abstract}

Keywords: Gilthead seabream, Vegetable meal, Squid meal, Krill meal, Intestine, Histology, Gene expression

\footnotetext{
* Correspondence: guiescu@etsia.upv.es

${ }^{1}$ Aquaculture and Biodiversity Research Group, Institute of Science and

Animal Technology, (ICTA), Universitat Politècnica de València, Camino de

Vera $s / n, 46022$ Valencia, Spain

Full list of author information is available at the end of the article
}

(c) The Author(s). 2018 Open Access This article is distributed under the terms of the Creative Commons Attribution 4.0 International License (http://creativecommons.org/licenses/by/4.0/), which permits unrestricted use, distribution, and

reproduction in any medium, provided you give appropriate credit to the original author(s) and the source, provide a link to the Creative Commons license, and indicate if changes were made. The Creative Commons Public Domain Dedication waiver (http://creativecommons.org/publicdomain/zero/1.0/) applies to the data made available in this article, unless otherwise stated. 


\section{Background}

Fishmeal replacement in feeds is one of the main challenges in aquaculture farming in order to ensure the sustainability of the production of aquaculture species, especially in carnivorous species [1]. Plant sources have been used as substitutes in order to reduce the use of fishmeal [2] and to develop more economical and environmentally sustainable feeds compared to fishmeal based diets $[1,3]$.

Tolerance to vegetable products depends on species [4]. In the case of gilthead seabream, although high or total replacements of fishmeal by vegetable meal have been successfully achieved in terms of growth $[5,6]$, detrimental effects on nutrient digestibility and absorption $[7,8]$ have also been reported. Moreover, histomorphological gut and liver alterations [4, 9-11], immune status disorders [9] or gut microbial imbalances [12] have been described. Thus, the use of certain agricultural by-products seems to ultimately lead to a lower feed conversion efficiency and an increase in both the susceptibility against diseases and bacterial and parasitic infections [13], which may be induced by an immune deficiency status or disruptions on the inflammatory response.

Hence, dietary and nutritional factors have a great influence on growth and immune response of fish [14]. Among other physiological processes, fish gut particularly plays a key role in the digestion and absorption of nutrients, in the immune response to potential pathogenic invasions and in the protection against environmental stressors [15]. The intestinal status in response to dietary changes has been widely assessed in fish, including gilthead seabream [16-21]. In particular, the impact of lowfishmeal diets on the intestinal physiology of different species has been assessed in different stages of the growing phase [22, 23].

A wide set of physiological parameters can be evaluated by using different techniques. Gene expression approaches allow to analyse different genes involved in different processes [24] including digestion (digestive enzymes, nutrient transporters), epithelial structure, inflammatory processes (cytokines and other proinflammatory mediators), and innate and adaptive immune response (mucins, genes codifying for antibodies), obtaining a snapshot of the whole response that can indeed provide hints and new insights to dietary impact on the intestinal status. On the other hand, histological assessment of the different gut layers can provide some valuable information on possible inflammatory reactions, as well as morphological adaptations to face with the dietary modifications [25].

In addition to detrimental effects associated to anti-nutritional factors [26, 27], whose impact depends on the tolerance of different species, fishmeal substitutions by great proportions of vegetable meals in fish diet could result in amino acid imbalances and palatability problems [1, 27], which could have an influence in the feed intake and negatively affect the fish performance [28]. In order to achieve the minimum requirements, diets with high fishmeal substitution usually need a supplement with synthetic amino acids that increases the price of the diet and could have different adverse effects in nutrient utilisation [29]. Nevertheless, the addition of complementary ingredients such as marine by-products, as opposed or in combination with the amino acid supplementation, seems to be more effective in order to achieve an ideal amino acid profile when alternative vegetable-based diets are used [28]. Indeed, marine by-products, including squid meal or krill meal, are regarded as a high quality protein source, since they show a balanced amino acid profile and contain a considerable amount of free amino acids [28]. Furthermore, these marine ingredients yield several profits, such as acting as feed-attractant that improves feed intake or offsetting some of the deficiencies observed with high plant protein diets for marine carnivorous fish [28, 30, 31].

This work focuses on the impact of a complete replacement of fishmeal during the on-growing period on the intestine of gilthead seabream through the gene expression study of a broad set of genes related to inflammatory response, immune system, gut epithelia integrity, digestive enzymes and peptide transporters. In addition, the effect of the inclusion of marine by-products (squid and krill meal) in seabream plant based diets as a source of marine protein was also assessed in terms of growth parameters and gene expression. The study was supplemented with histological analysis of the foregut, aiming to understand the possible effects in relation to nutrient absorption and inflammatory processes at the morphological level.

\section{Methods}

\section{Ethics statements}

The experimental protocol was reviewed and approved by the Committee of Ethics and Animal Welfare of the Universitat Politècnica de València, following the Spanish Royal Decree 53/2013 and the European Directive 2010/63/UE on the protection of animals used for scientific purposes.

Fish were weighed individually every month during the feed assay, using clove oil with an $87 \%$ of eugenol (Guinama ${ }^{\bullet}$, Valencia, Spain) as an anaesthetic $(1 \mathrm{mg} / 100 \mathrm{~mL}$ of water) to minimize their suffering.

At the end of the growth assay, fish were euthanized by decapitation, after fish were anesthetized with clove oil dissolved in water $(1 \mathrm{mg} / 100 \mathrm{~mL}$ of water $)$, thus minimizing their suffering. 


\section{Design of the experiment}

\section{Rearing system, fish and growth assay}

The experiment was conducted at the Universitat Politècnica de València in a recirculating saltwater system $\left(75 \mathrm{~m}^{3}\right.$ capacity) with a rotary mechanical filter and a $6 \mathrm{~m}^{3}$ capacity gravity biofilter. Nine cylindrical fiberglass tanks with a capacity of $1750 \mathrm{~L}$ were used, and water temperature, salinity, dissolved oxygen and $\mathrm{pH}$ were as follows: $22.0 \pm 0.52{ }^{\circ} \mathrm{C}, 30 \pm 1.7 \mathrm{~g} / \mathrm{L}, 6.5 \pm$ $0.49 \mathrm{mg} / \mathrm{L}, 7.5-8.5$. Water parameters were daily measured. All tanks had similar lighting conditions, with a natural photoperiod (from November to March, average of hours of light: $11 \mathrm{~h}$ ).

The seabreams were provided by the fish farm PISCIMAR, in Burriana (Castelló, Spain). The feed was given by hand twice a day (at 9:00 and 17:00 h) up to an apparent satiation with a standard commercial (48\% crude protein, $23 \%$ ether extract, $11 \%$ crude ash, $2 \%$ crude fibre and $14 \%$ nitrogen free extract) diet during the two-month acclimation period to laboratory conditions. The weekly feeding regimen consisted of six days of feeding and one day of fasting. Growth assay started with fish with an average weight of $129 \pm 19 \mathrm{~g}$.

Seabream were randomly distributed into 9 fiberglass tanks (twenty fish per tank), and three different experimental diets (a vegetable diet, VM; a fishmeal-based diet, FM and a vegetable diet with marine ingredients, $\mathrm{VM}+$ ) were randomly assigned to three of them $(n=3)$. Feeding parameters remained the same as during the acclimatation period. The experiment finished when the fish achieved a commercial size, (average weight $\sim 350 \mathrm{~g}$ ), and fish were sacrifice afterwards, 154 days after the beginning of the assay.

Fish weight (g) and survival rate (\%) were assessed monthly. Final weight (g) (FW), specific growth rate (\% / day) (SGR), feed intake (g/ $100 \mathrm{~g}$ fish · day) (FI), feed conversion ratio (FCR), and survival (\%) $(\mathrm{S})$ were determined when the experiment was completed. The SGR, the FI and the FCR were obtained taking into account the reported monthly biomass of dead fish.

\section{Diets}

Diets were prepared as pellets by cooking-extrusion with a semi-industrial twin-screw extruder (CLEXTRAL BC-45, Firminy, St Etienne, France); located at Universitat Politècnica de València. The processing conditions were as follows: $0.63 \mathrm{~g}$ screw speed, $110{ }^{\circ} \mathrm{C}$ and 30-40 atm.

Three isonitrogenous and isoenergetic diets were formulated using commercial ingredients, whose proximal composition was previously analysed according to AOAC (Association of Official Agricultural Chemists) procedures. in the FM diet, the protein was provided by fishmeal, although wheat meal was incorporated as a source of carbohydrates. Synthetic amino acids were not included. The
VM diet was based on a mixture of vegetable meals as a protein source and included synthetic amino acids in order to accomplish the minimum requirements of essential amino acids [32]. Finally, $\mathrm{VM}+$ contained a mixture of vegetable meals similar to the VM diet one, but squid meal and krill meal were added to the feed at 10 and 5\% level, respectively, reducing the concentration of free amino acid supplementation. These meals were obtained from different companies as by-products: squid meal was provided by Max Nollert (Utrecht, Netherlands) and krill meal by Ludan Renewable Energy (Valencia, Spain).

Amino acids of raw materials and experimental diets were analysed, prior to diet formulation, through a Waters HPLC system (Waters 474, Waters, Milford, MA, USA) consisting of two pumps (Model 515, Waters), an auto sampler (Model 717, Waters), a fluorescence detector (Model 474, Waters) and a temperature control module. Aminobutyric acid was added as an internal standard pattern before hydrolysation. The amino acids were derivatised with AQC (6-aminoquinolyl-N-hydroxysuccinimidyl carbamate). Methionine and cysteine were determined separately as methionine sulphone and cysteic acid after oxidation with performic acid. Amino acids were separated with a C-18 reverse-phase column Waters Acc. Tag $(150 \mathrm{~mm} \times 3.9 \mathrm{~mm})$. Proximate composition and essential amino acids of different ingredients are shown in Table 1. The ingredients used, the proximate composition and the essential amino acids of the experimental feeds are included in Table 2.

A digestibility experiment was performed after the growth assay, using five randomly selected fish per experimental group and digestibility tanks of $250 \mathrm{l}$ of capacity (one per experimental group). Apparent digestibility coefficient of the crude protein were obtained, according to the Guelph System Protocol [33], by the Chromium Oxide determination method. After two days of fasting, digestibility assay started and lasted 14 days. Fish were fed to satiation once a day (9:00 h) with the same experimental diets containing chromium oxide $\left(50 \mathrm{~g} \mathrm{~kg}^{-1}\right)$ as an innert marker and uneaten food was then removed from the columns (15:00). Wet faeces were collected from decantation columns just before the next morning feeding and then dried at $60{ }^{\circ} \mathrm{C}$ for $48 \mathrm{~h}$ prior to analysis. After acid digestion, an atomic absorption spectrometer (Perkin Elmer 3300, Perkin Elmer, Boston, MA, USA) was used for Chromium oxide determination in duplicate in diets and faeces. Apparent digestibility coefficient (ADC) of the crude protein (CP) was calculated as follows (Eq. 1):

$$
A D C_{N}(\%)=100 \cdot\left(1-\left(\frac{\% \text { marker in diet } \cdot \% C P \text { in faeces }}{\% \text { marker in faeces } \cdot \% \text { CP in diet }}\right)\right)
$$


Table 1 Proximal composition and essential amino acid profile of the different aqua feed ingredients

\begin{tabular}{|c|c|c|c|c|c|c|c|c|c|}
\hline & Fishmeal & $\begin{array}{l}\text { Wheat } \\
\text { meal }\end{array}$ & $\begin{array}{l}\text { Wheat } \\
\text { gluten }\end{array}$ & $\begin{array}{l}\text { Broad Bean } \\
\text { meal }\end{array}$ & $\begin{array}{l}\text { Soybean } \\
\text { meal }\end{array}$ & $\begin{array}{l}\text { Pea } \\
\text { meal }\end{array}$ & $\begin{array}{l}\text { Sunflower } \\
\text { meal }\end{array}$ & $\begin{array}{l}\text { Squid } \\
\text { meal }\end{array}$ & $\begin{array}{l}\text { Krill } \\
\text { meal }\end{array}$ \\
\hline \multicolumn{10}{|c|}{ Proximate composition (\% dry weight) } \\
\hline Dry matter & 90.3 & 87.8 & 93.3 & 89.0 & 88.1 & 86.6 & 89.6 & 88.0 & 88.8 \\
\hline Ash & 16.8 & 1.6 & 0.9 & 3.0 & 7.1 & 3.4 & 6.7 & 9.1 & 10.4 \\
\hline Crude lipid & 9.3 & 1.8 & 0.9 & 1.1 & 2.2 & 0.8 & 1.5 & 15.1 & 22.5 \\
\hline Crude fiber & 0.1 & 2.8 & 0.4 & 9.1 & 3.6 & 6.2 & 18.7 & 0.9 & $4.0^{*}$ \\
\hline $\begin{array}{l}\text { Non-starch } \\
\text { polyssaccharides }\end{array}$ & 2.6 & 23.8 & 17.2 & 33.3 & 32.4 & 29.9 & 50.1 & 4.7 & 11.0 \\
\hline Crude protein & 71.3 & 11.4 & 81.0 & 21.1 & 49.9 & 18.7 & 35.7 & 71.1 & 56.1 \\
\hline \multicolumn{10}{|c|}{ Essential amino acids (g $100 \mathrm{~g}^{-1}$ dry matter) } \\
\hline Arginine & 5.86 & 0.38 & 2.57 & 1.99 & 3.66 & 1.76 & 3.33 & 5.90 & 4.14 \\
\hline Histidine & 2.54 & 0.26 & 1.45 & 0.74 & 1.42 & 0.58 & 1.14 & 1.85 & 1.26 \\
\hline Isoleucine & 3.40 & 0.36 & 3.01 & 1.03 & 2.33 & 0.98 & 1.56 & 2.28 & 3.19 \\
\hline Leucine & 6.55 & 0.80 & 5.79 & 2.04 & 4.22 & 1.78 & 2.48 & 4.16 & 4.67 \\
\hline Lysine & 6.01 & 0.37 & 1.21 & 1.92 & 3.45 & 1.92 & 1.39 & 3.85 & 3.77 \\
\hline Methionine & 2.30 & 0.22 & 0.88 & 0.31 & 0.92 & 0.36 & 1.00 & 1.76 & 1.66 \\
\hline Phenylalanine & 3.73 & 0.49 & 4.31 & 1.10 & 2.60 & 1.11 & 1.86 & 2.14 & 2.97 \\
\hline Threonine & 3.55 & 0.30 & 1.95 & 0.94 & 1.98 & 0.86 & 1.52 & 2.19 & 2.74 \\
\hline Valine & 3.88 & 0.47 & 3.26 & 1.13 & 2.30 & 1.06 & 1.73 & 2.70 & 3.12 \\
\hline
\end{tabular}

* $4 \%$ of chitin

Origin and price of the different ingredients (ingredient, origin, price in $€$ kg ingredient ${ }^{-1}$ ): FM, Vicens i Batllori S. L. (Girona, Spain), 1.51; WM, Desco S. L. (Museros, Spain), 0.15; WG, Ercros S. A. (Barcelona, Spain), 0.76; BBM, Desco S. L. (Museros, Spain), 0.27; SBM, Desco S. L. (Museros, Spain), 0.31; PM, Desco S. L. (Museros, Spain), 0.23; SFM, Desco S. L. (Museros, Spain), 0.17; SM, Max Nollert (Utrecht, Netherlands), 4.28; KM, Ludan Renewable Energy (Valencia, Spain), 0.25

\section{Economic assessment}

The Economic Conversion Rate (ECR) and the Economical Profit Index (EPI) [2] were calculated for each experimental group using Eqs. (2) and (3), respectively. The currency type for economic evaluations was the euro $(€)$. The price of the diets was obtained from the individual prices of the different ingredients. Gilthead seabream sale price was $5.37 € \mathrm{Kg}$ fish $^{-1}$, based on prices of the Spanish Wholesale market on January 2017. With the aim of showing the impact of the fish mortality on economic profit in on-growing phase, biomass of dead fish was considered and therefore was not included in the total final biomass, and the initial number of fish was used to standarize when the EPI was determined.

$$
\begin{aligned}
\operatorname{ECR}(€ \cdot \mathrm{kg} \mathrm{fish} & -1)= \\
& \text { FCR }\left(\mathrm{kg} \operatorname{diet} \cdot \mathrm{kg} \mathrm{fish}{ }^{-1}\right) \\
& \cdot \text { Price of diet }\left(€ \cdot \mathrm{kg} \mathrm{diet}^{-1}\right)
\end{aligned}
$$

\section{Sampling}

In order to assess gene expression and histological changes throughout the intestinal tract, intestinal samples from three fish per tank were sampled at the end of the growth assay after one day of fasting ( $40 \mathrm{~h}$ after the last feed). Based on the separation on sections proposed in previous researches [34], three different sections were considered but only pieces of foregut (FG) and hindgut (HG) were collected and stored in RNA later(Ambion Inc., Huntingdon, UK) at $4{ }^{\circ} \mathrm{C}$ overnight and then at $-20^{\circ}$ $\mathrm{C}$ until RNA extraction. Pieces of FG section (two fish per tank, $n=6$ ) were stored in phosphate buffered formalin (4\%, pH 7.4) for the histological assessment.

\section{Gene expression}

\section{RNA extraction and $C D N A$ step}

Total RNA was extracted from FG and HG tissues by traditional phenol/chloroform extraction, using TRIzol Reagent (Invitrogen, Spain), and then purified and treated with DNase I using NucleoSpin ${ }^{\circledR}$ RNA Clean-up XS kit (Macherey-Nagel, Düren, Germany), according to

$\operatorname{EPI}\left(€ \cdot\right.$ fish $\left.^{-1}\right)=\frac{\text { Final biomass }(\mathrm{kg} \text { fish }) \cdot \text { Sale price }\left(€ \cdot \mathrm{kg} \mathrm{fish}^{-1}\right)-\Delta \text { biomass }(\mathrm{kg} \text { fish }) \cdot \mathrm{ECR}\left(€ \cdot \mathrm{kg} \text { fish }^{-1}\right)}{\text { Initial number of fish }}$ 
Table 2 Price, ingredients,proximal composition and essential amino acid profile of diets tested in the growth assay

\begin{tabular}{|c|c|c|c|}
\hline & VM & FM & VM+ \\
\hline$\overline{\text { Price }\left(€ \mathrm{~kg}^{-1}\right)^{*}}$ & 0.79 & 1.09 & 1.05 \\
\hline \multicolumn{4}{|l|}{ Ingredients $\left(\mathrm{g} \mathrm{kg}^{-1}\right)$} \\
\hline Fishmeal & & 589 & \\
\hline Wheat meal & & 260 & \\
\hline Wheat gluten & 295 & & 222 \\
\hline Broad bean meal & 41 & & 40 \\
\hline Soybean meal & 182 & & 160 \\
\hline Pea meal & 41 & & 40 \\
\hline Sunflower meal & 158 & & 160 \\
\hline Krill meal & & & 50 \\
\hline Squid meal & & & 100 \\
\hline Fish oil & 90 & 38.1 & 77.5 \\
\hline Soybean oil & 90 & 92.9 & 77.5 \\
\hline Soy Lecithin & 10 & 10 & 10 \\
\hline Vitamin-mineral mix ${ }^{* *}$ & 10 & 10 & 10 \\
\hline Calcium phosphate & 38 & & 38 \\
\hline Arginine & 5 & & \\
\hline Lysine & 10 & & 10 \\
\hline Methionine & 7 & & 5 \\
\hline Taurine & 20 & & \\
\hline Threonine & 3 & & \\
\hline \multicolumn{4}{|c|}{ Proximate composition (\% dry weight) } \\
\hline Dry matter & 93.9 & 88.1 & 92.83 \\
\hline Ash & 7.4 & 10.1 & 8.8 \\
\hline Crude lipid & 19.8 & 18.5 & 20 \\
\hline Crude fiber & 4.3 & 0.8 & 4.6 \\
\hline Non-starch polyssaccharides & 21.5 & 7.7 & 20.6 \\
\hline Crude protein & 45.0 & 44.2 & 44.6 \\
\hline Digestible protein $* * *$ & 41.8 & 42.7 & 42.0 \\
\hline \multicolumn{4}{|l|}{ Essential amino acids $\left(\mathrm{g} 100 \mathrm{~g}^{-1}\right.$ ) } \\
\hline Arginine & 3.30 & 3.39 & 3.58 \\
\hline Histidine & 0.82 & 1.00 & 0.81 \\
\hline Isoleucine & 1.17 & 1.47 & 1.08 \\
\hline Leucine & 2.98 & 3.24 & 2.45 \\
\hline Lysine & 2.26 & 3.68 & 2.38 \\
\hline Methionine & 1.06 & 1.16 & 1.05 \\
\hline Phenylalanine & 1.87 & 1.80 & 1.76 \\
\hline Threonine & 1.44 & 1.98 & 1.28 \\
\hline Valine & 1.47 & 2.01 & 1.32 \\
\hline
\end{tabular}

* The price of the diets was obtained from the individual prices of the different marine and vegetable meals (included in Table 1) and the other ingredients (price in $€ \mathrm{~kg}^{-1}$ ingredient): soybean oil, 0.63; soy lecithin, 1.15; vitamin-mineral mix, 2.75; calcium phosphate, 2.07; arginine, 7.64; lysine, 1.68; methionine, 3.52; taurine, 2.20; threonine, 1.30

**Vitamin and mineral mix (values are $\mathrm{g} \mathrm{kg}-1$ except those in parenthesis): Premix, 25; choline, 10; DL-a-tocopherol, 5; ascorbic acid, 5; (PO4)2Ca3, 5. The
Premix is composed of: retinol acetate, 1,000,000 (IU kg - 1); calcipherol, 500 (IU kg - 1); DL-a-tocopherol, 10; menadione sodium bisulphite, 0.8; thiamine hydrochloride, 2.3; riboflavin, 2.3; pyridoxine hydrochloride, 15;

cyanocobalamine, 25; nicotinamide, 15; pantothenic acid, 6; folic acid, 0.65; biotin, 0.07; ascorbic acid, 75; inositol, 15; betaine, 100; polypeptides, 12

***Digestible protein $=$ Crude protein $\times A D C C P ; A D C C P=$ Apparent Digestibility Coefficient of Protein: $A D C C P(V M)=0,93$

$\mathrm{ADCCP}(\mathrm{FM})=0,97 ; \mathrm{ADCCP}(\mathrm{VM}+)=0,94$

guide instructions. Total RNA concentration, quality and integrity were evaluated using a NanoDrop 2000C Spectrophotometer (Fisher Scientific SL, Spain) and samples were stored at $-80{ }^{\circ} \mathrm{C}$ until complementary DNA (cDNA) synthesis.

cDNAwas synthetized from $1 \mu \mathrm{g}$ of total RNA input using the qScript cDNA Synthesis Kit (Quanta BioScience), according to the manufacturer's instructions, using the Applied Biosystems 2720 Thermal Cycler. The cycling conditions were $22{ }^{\circ} \mathrm{C}$ for $5 \mathrm{~min}, 42{ }^{\circ} \mathrm{C}$ for $30 \mathrm{~min}$, and $85{ }^{\circ} \mathrm{C}$ for 5 min. Total RNA samples were stored at $-80{ }^{\circ} \mathrm{C}$ until gene expression was analysed.

\section{Measurement of gene expression by SYBR green assay real time quantitative RT-PCR (qPCR) Reference and target genes}

Four candidate reference genes (ef1 $\alpha$, gapdh, rps18, $\beta$ act; Table 3) were tested to be used as housekeeping genes in the gene expression assay. The stability of these genes was determined using six cDNA pooled samples, obtained each one from combine equally volumes of cDNA samples from the same section in a given experimental group. Ribosomal protein s18 (rps18) and $\beta$-actin ( $\beta a c t)$ were selected as reference genes for the normalization of gene expression based on the stability of its expression in the cDNA pools and the cDNA specificity in the amplification, confirmed by melting curve analysis [see Additional file 1].

Expression stability of reference genes in individualized samples was determined using the BestKeeper program [35], which reports a standard deviation $(\mathrm{SD}[ \pm \mathrm{Cq}])$ lower than 1 for both genes ( 0.54 for rps 18 and 0.68 for Bact, $p$ $<0.05)$ and $\mathrm{Cq}$ arithmetic means of $20.19 \pm 1.46$ and $17.96 \pm 1.6$ for rps18 and Bact, respectively. The BestKeeper's calculated variations in the reference genes are based on the arithmetic mean of the Cq values.

Eighteen candidate target genes (Table 3) were previously tested by RT-qPCR. The proinflammatory cytokines genes $i l 1 \beta$, il6 and $i l 8$, and other proinflammatory molecules, as tnfo, casp1 AND cox 2 were included due to their relevance as inflammation markers $[16,20]$. Genes encoding different mucins (imuc, muc2, muc2L, muc13 and muc19), which contribute to protect the intestine epithelium against a broad spectrum of damages [19], and specific antibodies (igm) were also chosen to assess the response of the innate and adaptive immunity, respectively. A tight junction protein, such as $o c l$, and an essential component of microtubules such as tub [16] were included in the expression 
Table 3 Primer sequences of candidate genes (reference and target genes) in the RT-qPCR assay

\begin{tabular}{|c|c|c|c|c|c|c|}
\hline Gene & Abbreviation & GeneBank ID & Primer Forward & Primer Reverse & Lenght & Reference \\
\hline \multicolumn{7}{|l|}{ REFERENCE GENES } \\
\hline Elongation Factor $1 a$ & efia & AF184170 & CTGTCAAGGAAATCCGTCGT & TGACCTGAGCGTTGAAGTTG & 87 & {$[16,20]$} \\
\hline $\begin{array}{l}\text { Glyceraldehide 3-phosphate } \\
\text { dehydrogenase }\end{array}$ & gapdh & DQ641630 & CCAACGTGTCAGTGGTTGAC & AGCCTTGACGACCTTCTTGA & 80 & {$[17]$} \\
\hline Ribosomal Protein S18 & $\operatorname{rps} 18$ & AM490061 & AGGGTGTTGGCAGACGTTAC & CGCTCAACCTCCTCATCAGT & 97 & [17] \\
\hline$\beta$-Actin & Bact & X89920 & TCTGTCTGGATCGGAGGCTC & AAGCATTTGCGGTGGACG & 113 & [19] \\
\hline \multicolumn{7}{|l|}{ TARGET GENES } \\
\hline Interleukin $1 \beta$ & $i / 1 \beta$ & AJ277166 & GCGACCTACCTGCCACCTACACC & TCGTCCACCGCCTCCAGATGC & 131 & {$[17]$} \\
\hline Interleukin 6 & il6 & AM749958 & AGGCAGGAGTTTGAAGCTGA & ATGCTGAAGTTGGTGGAAGG & 101 & [16] \\
\hline Interleukin 8 & i/8 & JX976619 & GCCACTCTGAAGAGGACAGG & TTTGGTTGTCTTTGGTCGAA & 164 & {$[16,20]$} \\
\hline Tumor Necrosis Factor a & tnfa & AJ413189 & CAGGCGTCGTTCAGAGTCTC & GAGATCCTGTGGCTGAGAGG & 83 & {$[17]$} \\
\hline Cyclooxygenase 2 & $\cos 2$ & AM296029 & GAGTACTGGAAGCCGAGCAC & GATATCACTGCCGCCTGAGT & 192 & {$[16,20]$} \\
\hline Caspase 1 & casp 1 & AM490060 & ACGAGGTGGTGAAACACACA & GTCCGTCTCTTCGAGTTTCG & 92 & [16] \\
\hline Intestinal Mucin & imuc & JQ277712 & GTGTGACCTCTTCCGTTA & GCAATGACAGCAATGACA & 102 & [19] \\
\hline Mucin 2 & muc2 & JQ277710 & ACGCTTCAGCAATCGCACCAT & CCACAACCACACTCCTCCACAT & 90 & [19] \\
\hline Mucin 2-like & muc2l & JQ277711 & $\begin{array}{l}\text { GTGTGTGGCTGTGTTCCTTGCTTI } \\
\text { GT }\end{array}$ & $\begin{array}{l}\text { GCGAACCAGTCTGGCTTGG } \\
\text { ACATCA }\end{array}$ & 67 & [19] \\
\hline Mucin 13 & mucl3 & JQ277713 & TTCAAACCCGTGTGGTCCAG & $\begin{array}{l}\text { GCACAAGCAGACATAGTTC } \\
\text { GGATAT }\end{array}$ & 67 & [19] \\
\hline Mucin 19 & muc19 & JQ277715 & TGCTTGCTGATGACACAT & TTCACATAGGTCCAGATATTGA & 128 & [19] \\
\hline Immunoglobulin M & igm & JQ811851 & $\begin{array}{l}\text { TCAGCGTCCTTCAGTGTTTATGAT } \\
\text { GCC }\end{array}$ & $\begin{array}{l}\text { CAGCGTCGTCGTCAACAAG } \\
\text { CCAAGC }\end{array}$ & 131 & [18] \\
\hline Occludin & ocl & JK692876 & GTGCGCTCAGTACCAGCAG & TGAGGCTCCACCACACAGTA & 81 & {$[16,20]$} \\
\hline Tubulin & tub & AY326430 & AAGATGTGAACTCCGCCATC & CTGGTAGTTGATGCCCACCT & 98 & [16] \\
\hline a-Amylase & aamy & AF316854 & TGGTGGGACAATCAGAGTCA & GTCCAGGTTCCAGTCGTCAT & 85 & {$[16,20]$} \\
\hline Alkaline phosphatase & alp & AY266359 & TTACTGGGCCTGTITGAACC & GATCTTGATGGCCACTTCCAC & 102 & {$[16,20]$} \\
\hline Trypsin & tryp & AF316852 & GGTCTGCATCTTCACCGACT & AAAGGCAGCAGAGTGATGGT & 85 & [20] \\
\hline Peptide transporter 1 & pept1 & GU733710 & TTGAACATAACGTCGGGTGA & AATTTTGCATTTCCCTGTGG & 92 & [16] \\
\hline
\end{tabular}

pretesting due to their involvement in the maintenance of the epithelial gut integrity. Regarding the selected genes encoding digestive enzymes and nutrient transporters, xamy and tryp are digestive enzymes responsible for hydrolysis of carbohydrates and proteins, respectively, and pept1 is a peptide transporter at the brush border membrane of the enterocytes with an important role in the intestinal absorption [36]. Finally, the gene expression of the alp, responsible of removing the phosphate groups of many different molecules [37], was also determined.

This preliminary gene expression test was performed using the cDNA pooled samples used in the reference gene evaluation [see Additional file 2]. Target genes for the further individualized assesment were selected based on their function, potential fold-change differences between diets and intestine segments (significant differences cannot be determined by an statistical analysis since $n=1$ ), gene expression level and nonspecific amplifications. Later on, relative gene expression of the nine selected genes (il1 $\beta, i l 6$, cox2, igm, imuc, ocl, pept1, tryp, alp) was determined at the FG and at the HG in nine fish per dietary treatment.

\section{RT-PCR assay conditions}

All qPCR assays and expression analyses were performed using the Applied Biosystems 7500 Real-Time PCR with SYBR $^{\circ}$ Green PCR Master Mix (ThermoFisher Scientific, Waltham, Massachusetts, USA). The total volume for every PCR reaction was $10 \mu \mathrm{L}$, performed from diluted (1:50) cDNA template $(1 \mu \mathrm{L})$, forward and reverse primers $(10 \mu \mathrm{M}, 1 \mu \mathrm{L})$, SYBR ${ }^{\circ}$ Green PCR Master Mix $(5 \mu \mathrm{L})$ and nuclease-free water up to $10 \mu \mathrm{L}$.

After an initial Taq activation of polymerase at $95{ }^{\circ} \mathrm{C}$ for $10 \mathrm{~min}, 42$ cycles of PCR were performed with the following cycling conditions: $95{ }^{\circ} \mathrm{C}$ for $10 \mathrm{~s}$ and $60{ }^{\circ} \mathrm{C}$ for $20 \mathrm{~s}$ in all genes, except for alp (with annealing and extension step at $55^{\circ} \mathrm{C}$ ). In order to evaluate assay specificity, a melting curve analysis was directly performed after PCR by slowly increasing the temperature $\left(1{ }^{\circ} \mathrm{C} / \mathrm{min}\right)$ from 60 to $95{ }^{\circ} \mathrm{C}$, with a 
continuous registration of changes in fluorescent emission intensity.

The analysis of the results was carried out using the $2^{-\Delta \Delta \mathrm{Ct}}$ method [24]. The target gene expression quantification was expressed relative to the expression of the two reference genes (rps18 and $\beta a c t)$. A cDNA pool from all the samples was included in each run and acted as a calibrator, and a non-template control for each primer pair, in which cDNA was replaced by water, was run on all plates. Reference and target genes in all samples were run in duplicate PCR reactions.

\section{Histological analysis}

Fragments of FG fixed in formalin were routinely dehydrated in ethanol, equilibrated in UltraClear (Bio-Optica Milano s. p. a., Milan, Italy), and embedded in paraffin according to standard histological techniques. Transverse sections were cut with a thickness of $5 \mu \mathrm{m}$ with a microtome Shandom Hypercut (four sections per paraffin block were obtained) and dyed with the haematoxylin-eosine staining method. A total of 72 FG sections, obtained from 18 different paraffin blocks $(n=6)$, were analysed under the light microscope (Nikon, Phase Contrast Dry JAPAN 0.90 ), focusing on possible inflammatory changes and other disorders.

A combination of different criteria reported by several authors $[7,9,38-40]$ was used to measure the following parameters at FG sections: serous layer (SL), muscular layer (ML), submucosa layer (SML), villi length $(\mathrm{VL})$, villi thickness (VT) and lamina propria thickness (LP), and number of goblet cells per villus (GC). Six measurements per section in each parameter were performed and average means were obtained for each sample $(n=6)$. Moreover, a continuous scoring system (Fig. 1), ranging from 1 to 4 , was used to assess the supranuclear vacuolization on the epithelia $(\mathrm{V})$, the position of the nuclei of the enterocytes (EN) and the lymphocytic infiltration of the epithelial layer (EI), the lamina propria (LPI) and the submucosa (SMI) in each sample $(n=6)$.

\section{Statistics}

Statistical data analyses were carried out with Statgraphics (c) Centurion XVI software (Statistical Graphics Corp., Rockville, MO, USA).

Differences in fish weight and survival between dietary groups were monthly evaluated by simple analysis of variance, considering the tank as the experimental unit. At the end of the growth trial, economic indeces (ECR and EPI) and livestock data (FW, SGR, FCR, FI and S) were subjected to simple variance analysis. Each group in the calculation represented the combined group of fish per single tank (triplicate tanks per treatment). Student Newman-Keuls test was used to assess specific differences among dietary groups at the 0.05 significance level. Descriptive statistics are shown as the mean \pm pooled standard error of the mean (SEM).

Relative gene expression data was statistically analysed by two-way analysis of variance using Newman-Keuls test. Differences in expression were considered statistically significant when $p<0.05$. Data was expressed with the mean and the standard error for each gut section and experimental group. Differences in the gene expression between sections within each group, between experimental groups, and between same sections in different dietary groups were determined.

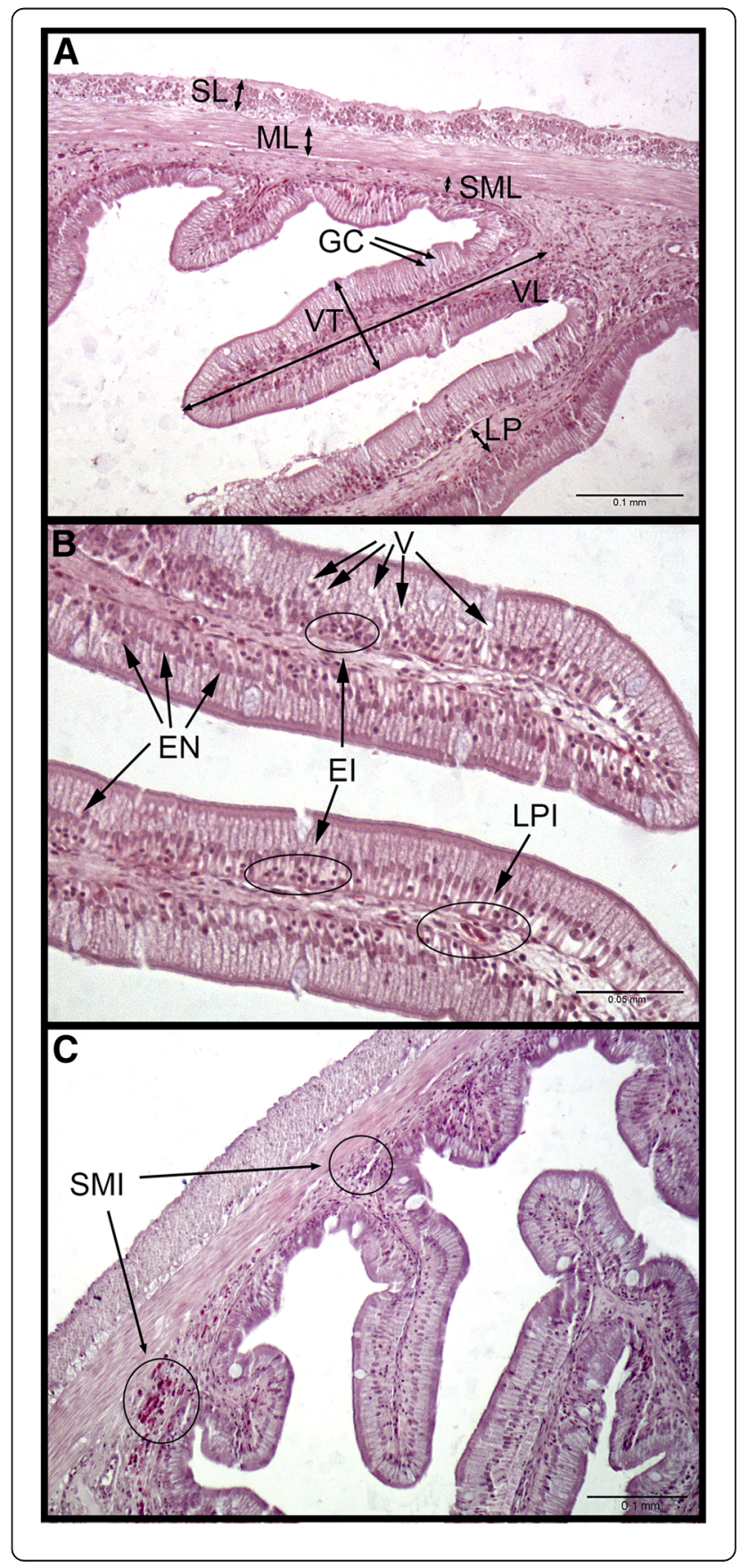


(See figure on previous page.)

Fig. 1 Evaluation and scoring system used to assess histological parameters of gilthead seabream foregut. a Measurements performed in a foregut histological section (20x). b Detail of villi with a certain grade of infiltration of the lamina propia and the epithelia. Enterocytes nuclei were displaced in some cases. Epithelial vacuolization can also be observed in a normal grade (40x). c Enterocytes showed aligned nuclei in a basal position. Villi presented a low grade of infiltration of their lamina propia and of the epithelia, and low vacuolization. A certain grade of infiltration in the submucosa layer can be observed (20X). SL, $\mathrm{ML}, \mathrm{SML}, \mathrm{VL}, \mathrm{VT}$ and number of GC were measured six times per section, and averages were obtained for each section (six sections per group, $n$ =6). $\mathrm{V}, \mathrm{EN}, \mathrm{El}, \mathrm{LPI}$ and SMI were assessed in each section $(n=6)$ using the following scoring system: $V$, normal (1) to hypervacuolated (4); EN, basal (1) to apical (4); El, low (1) to markedly increased (4); LPI, low (1) to markedly increased (4); SMI, low (1) to markedly increased (4). SL, serous layer; ML, muscular layer; SML, submucosa layer; $\mathrm{VL}$, villi length; $\mathrm{VT}$, villi thickness; LP, lamina propria; GC, goblet cells; V, supranuclear absorptive vacuoles; EN, enterocytes nuclei; El, epithelial infiltration; LPI, lamina propria infiltration; SMl, submucosa infiltration

Finally, histological measurements in foregut were showed as the mean \pm standard error of the mean and it was analysed through an analysis of variance (ANOVA), with a Newman-Keuls test for the comparison of the means and a level of significance set at $p<0.05$. Principal Component Analysis was used to analyse the histological scored parameters of gut (V, EN, EI, LPI and SMI). Statistical differences between experimental groups were estimated by ANOVA using the first and second Principal Components of the Principal Component Analysis, with a Newman-Keuls test $(p<0.05)$.

\section{Results}

\section{Economic indices}

Statistically differences were determined in the ECR between the groups FM and VM $(p=0.0473)$, whilst the EPI was greater in the groups FM and VM+ $(p=0.0167)$ (Table 4). Differences in the ECR can be explained by the greater cost of the FM feed, while the lower number of fish at the end of the growth assay in the different tanks assigned to the VM treatment led to a lower EPI $(p=0.0167)$ in this dietary group.

\section{Growth assay and growth indices}

Differences were observed in the average weight of fish after 112 days from the beginning of the growth assay $(p=0.0042)$, registering greater weight in those fish fed FM and VM+ than in fish fed VM (Fig. 2), although no significant differences were observed in subsequent sampling points and at the end of the feeding trial (Table 4). Survival rate of fish fed VM began to decrease after 112 days $(p=0.0332)$ of the experiment in comparison to the rates observed in the other two groups (FM and $\mathrm{VM}+$ ). Survival rate continued decreasing at VM group
Table 4 Growth and economic indices of seabream fed experimental diets at the end of the experiment

\begin{tabular}{llllll}
\hline & FM & VM & VM+ & SEM & $p$-value \\
\hline Initial Weight (g) & 131.2 & 127.2 & 129.6 & 4.1 & 0.9023 \\
Final Weight (g) & 393.1 & 360.4 & 384.6 & 13.2 & 0.2703 \\
Specific Growth Rate (\% / day) & 0.72 & 0.69 & 0.73 & 0.03 & 0.6562 \\
Feed Intake (g / 100 g fish · day) & 1.35 & 1.38 & 1.33 & 0.02 & 0.2758 \\
Feed Conversion Ratio & 2.14 & 2.40 & 2.08 & 0.10 & 0.1536 \\
Survival (\%) & $88.3^{\mathrm{a}}$ & $60.0^{\mathrm{b}}$ & $86.7^{\mathrm{a}}$ & 5.18 & 0.0141 \\
Economic Conversion Rate & $2.35^{\mathrm{a}}$ & $1.90^{\mathrm{b}}$ & $2.24^{\mathrm{ab}}$ & 0.10 & 0.0473 \\
(€ / kg fish)* & & & & & \\
Economic Profit Index (€/ fish)* & $1.36^{\mathrm{a}}$ & $0.99^{\mathrm{b}}$ & $1.33^{\mathrm{a}}$ & 0.07 & 0.0167
\end{tabular}

*Price of diets: $\mathrm{VM}=0.79 € ; \mathrm{FM}=1.09 € ; \mathrm{VM}+=1.05 €$. Sale price of gilthead seabream $=5.37 € \mathrm{~kg}_{\text {fish }}^{-1}$

Means of triplicate groups $(n=3)$. Data in the same row with different superscript letters differ at $p<0.05$

Initial Weight (g); Final Weight (g); Specific Growth Rate $\left(\%\right.$ day $\left.^{-1}\right)=100 \cdot \cdot$ In (final weight (g)/ initial weight (g)) / days; Feed Intake $\left(\mathrm{g} 100 \mathrm{~g} \mathrm{fish}^{-1} \mathrm{day}^{-1}\right)=$ 100 - feed consumption (g) / (average biomass (g). days); Feed Conversion Ratio = feed offered $(\mathrm{g}) /$ weight gain $(\mathrm{g})$; Survival $(\%)=100 \cdot$ (final number of fish / initial number of fish); Economic Conversion Rate (€ $\mathrm{kg} \mathrm{fish}^{-1}$ );

Economical Profit Index $(€)$

SEM Standard error of the mean

as the growth trial progressed, but no disease signs were reported in dead fish. No differences were observed in the growth parameters, which are shown in Table 4.

\section{Gene expression}

\section{Inflammation and immune system genes}

The diet was determined as a significant factor affecting the expression of $i l 1 \beta$, il6, cox 2 and igm (Table 5). Fish fed VM and FM reported lower expression levels of il1 $\beta$ (Fig. 3a), cox2 (Fig. 3c) and IgM (Fig. 3d) in comparison to $\mathrm{VM}+$ group, and a lower expression of il6 (Fig. 3b) was observed in the VM group. IgM and $i$-muc relative expression were affected by the section (Table 5): igm (Fig. 3d)

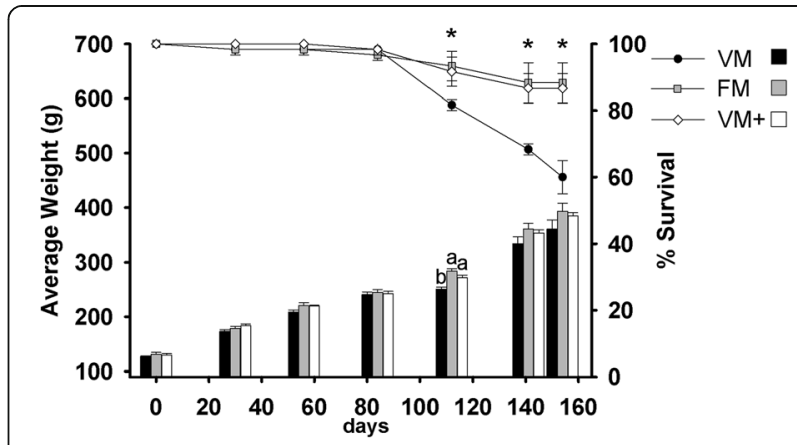

Fig. 2 Average weight (g) and survival rate (\%) evolution of gilthead seabream along the assay period. Average weight mean and standard error (bars) and survival rate (line) of each experimental group were displayed in different colours (Black: VM; Grey: FM; White: VM+). Different superscripts on the bars indicate significant statistical differences in the average weight during the growth trial $(p<0.05)$. Data are means of triplicate groups $(n=20)$. Asterisks indicate the existence of significant differences in the survival rate along the assay at $p<0.05$ 
Table 5 -values* determined for diet, intestinal section and the interaction between both factors on the gene expression assay

\begin{tabular}{llll}
\hline Gene & Diet & Section & Diet $\times$ section \\
\hline il1 $\beta$ & $<0.05$ & $\mathrm{~ns}$ & $\mathrm{~ns}$ \\
il6 & $<0.05$ & $\mathrm{~ns}$ & $\mathrm{~ns}$ \\
cox2 & $<0.01$ & $\mathrm{~ns}$ & $\mathrm{~ns}$ \\
igm & $<0.0001$ & $<0.05$ & $<0.05$ \\
imuc & $\mathrm{n} . \mathrm{s}$. & $<0.01$ & $\mathrm{~ns}$ \\
ocl & $<0.01$ & $\mathrm{~ns}$ & $\mathrm{~ns}$ \\
alp & $<0.01$ & $\mathrm{~ns}$ & $\mathrm{~ns}$ \\
tryp & $\mathrm{ns}$ & $\mathrm{ns}$ & $\mathrm{ns}$ \\
pept1 & $<0.05$ & $<0.0001$ & $\mathrm{~ns}$ \\
\hline
\end{tabular}

${ }^{*} p$-values were obtained using the Student Newman-Keuls test in a two way analysis of variance ns Non significant

had a higher expression in FG than in HG, specially in the group $\mathrm{VM}+$, and $i$-muc (Fig. 3e) reported a remarkably higher expression in the HG.

\section{Structural, enzyme and nutrient transport genes}

Expression of ocl, alp and pept 1 was influenced by the diet (Table 5). The VM group showed a lower expression of ocl (Fig. 3f) and alp (Fig. 3g) in comparison to the other two groups. Additionally, this group showed a lower expression of pept1 (Fig. 3i) in comparison to FM, but a greater expression compared to $\mathrm{VM}+$.The relative gene expression of tryp (Fig. 3h) showed a large individual variation and no differences were found at diet $(p=0.4677)$ or section level $(p$ $=0.2036$ ). Finally, the expression of pept 1 was also affected by the section (Table 5), being overexpressed in the FG compared to HG in all experimental groups (Fig. 3i).

\section{Histological analysis}

Fish fed VM exhibited thinner villi and lamina propria than the fish fed the FM diet (Table 6). No differences were determined in the thickness of the three layers of the intestinal wall, nor in the length of the villi and the thickness of the lamina propria. The number of GC was increased in many of the fish fed the vegetable diets, especially for the fish fed VM+, although no significant differences were determined between dietary groups.

Assessment by scoring of different parameters of the gut (Fig. 4) revealed differences on the number of supranuclear absorptive vacuoles in the epithelial layer $(\mathrm{V})$, the displacement of the enterocytes nuclei to apical positions (EN), and the degree of inflammatory cells infiltration in the submucosa layer (SMI). In these three assessed parameters, related with the inflammatory status,higher values were reported in the foregut sections belonging to $\mathrm{VM}$ and $\mathrm{VM}+$ groups. Dispersion graph (Fig. 4) based on the First and Second component values obtained from the Principal
Component Analysis, showed evident differences among the sections belonging to FM group and the sections from groups fed with plant-based diets. First Component of the Principal Component Analysis explained the 53,7\% of the variability and was related with the degree of inflammation. In this sense, an ANOVA taking this First Component as a variable confirmed the existence of significant differences $(p=0.0063)$ between FM sections and sections of the groups of fish fed vegetable diets (VM and $\mathrm{VM}+$ ).

Summarizing, the VM group registered greater mortality and lower expression of $i l 6, o c l$, alp and pepT1 at intestinal level, while the $\mathrm{VM}+$ group registered higher expression of $i l 1 \beta, \operatorname{cox} 2$ and igm and lower expression of pept1. At histological level, both dietary groups (VM and $\mathrm{VM}+$ ) reported thinner villi in the foregut compared to the FM group, an apical displacement of the enterocytes nuclei and higher vacuolization and cellular infiltration in the submucosa.

\section{Discussion}

\section{Zootecnical and economical parameters}

Based on the evolution of mean weight and survival rates, the impact of the different feeds on the growth and survival can be observed from 112 days of the growth assay. However, although survival rates of fish fed the VM diet decreased from this time until the end of the trial, no significant differences in terms of mean weight were registered at the 140 and 154 days. Dead fish found in the VM tanks in the final stage of the assay were mainly the smallest fish in these tanks, which could explain the disappearance of significant differences in the mean weight at the end of the trial. Variability in the different experimental groups prevents differences in growth indices," specially on the FCR. The less growth performance and greater mortality reported in the VM group are manifested in the economic indices. In this sense, FM and VM+ diets showed a similar efficiency under a economical point of view.

\section{Intestinal status}

Fish perfomance, including growth and survival, could be compromised by alterations in the intestinal homeostasis [11].

Fishmeal replacement by different vegetable sources has been associated with occurrence of gut inflammation in different species [41, 42]. Previous research have reported the up-regulation of the expression of different inflammatory markers [22, 23, 43, 44], higher grade of cell infiltration in the submucosa and changes in the expression of genes related with several processes, including antioxidant defences, cell differentiation, epithelial permeability, immunity and mucus production $[22,43]$ in response to moderate and high levels of plant protein sources inclusion.

In the present work, the group $\mathrm{VM}+$, in which fishmeal was totally replaced by plant sources and squid and krill meal were included at 15\% level, reported the up-regulation 


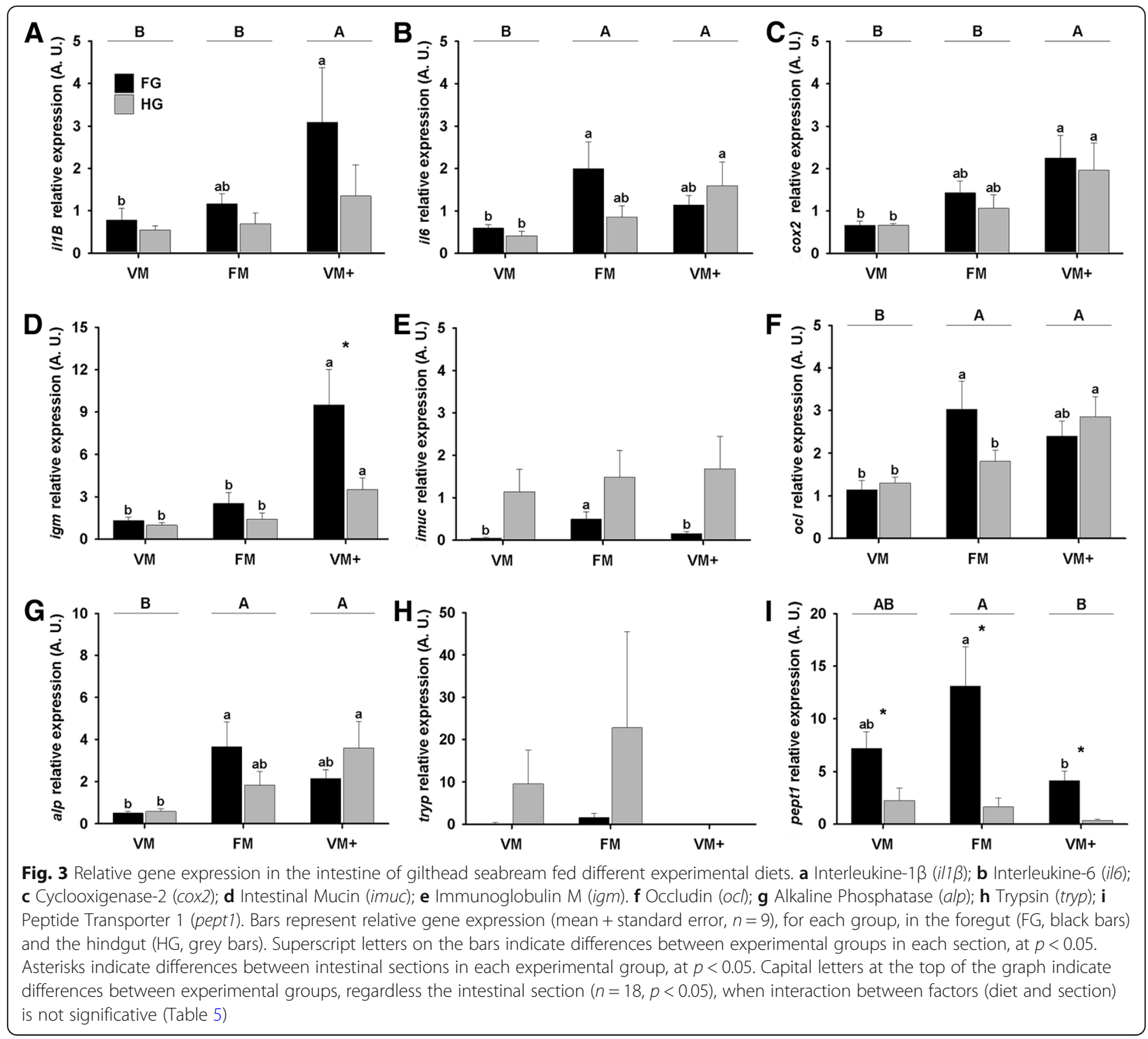

Table 6 Dietary effect on the histomorphology of the foregut of gilthead seabream

\begin{tabular}{llllll}
\hline & FM & VM & VM+ & SEM & p-values \\
\hline Serous layer $(\mu \mathrm{m})$ & 50.3 & 52.9 & 61.7 & 5.2 & 0.1275 \\
Muscular layer $(\mu \mathrm{m})$ & 58.4 & 56.6 & 55.8 & 5.4 & 0.8000 \\
Submucosa layer $(\mu \mathrm{m})$ & 44.3 & 40.4 & 43.0 & 4.5 & 0.6689 \\
Villi length $(\mu \mathrm{m})$ & 621.7 & 512.2 & 568.7 & 57.4 & 0.2545 \\
Villi thickness $(\mu \mathrm{m})$ & $101.1^{\mathrm{a}}$ & $85.2^{\mathrm{b}}$ & $93.4^{\mathrm{ab}}$ & 4.1 & 0.0009 \\
Lamina propria $(\mu \mathrm{m})$ & $14.2^{\mathrm{a}}$ & $9.9^{\mathrm{b}}$ & $14.0^{\mathrm{a}}$ & 1.3 & 0.0001 \\
Goblet cells & 3.2 & 4.4 & 4.9 & 1.1 & 0.1222 \\
\hline
\end{tabular}

Means were calculated from the average mean of each sample $(n=6)$. Data in the same row with different superscript letters differ at $p<0.05$ SEM Standard error of the mean of pro-inflammatory markers (ill $\beta$ and cox 2 ) and igm compared to the FM group. The increase of gene expression in relation to inflammatory mediators has been linked to the regulation of the inflammation [20] and the activation of the innate immunity in response to infection [45], and it has been observed as a common response against low fishmeal based diets in several species [23]. Although IgT has been recently suggested as the main inmunoglobulin in the mucosal responses in gilthead seabream [46], IgM plays a key role in the gut mucosal immune reactions against pathogens or environmental stress, and also in the triggering of the humoral response $[18,47]$. Additionally, high levels of IgM in the gut mucosa of fish fed with plant sources based diets have been reported [48]. Thus, the up-regulation of these genes could reflect that fish fed VM+ were developing an inflammatory process at the intestinal mucosa level, and 

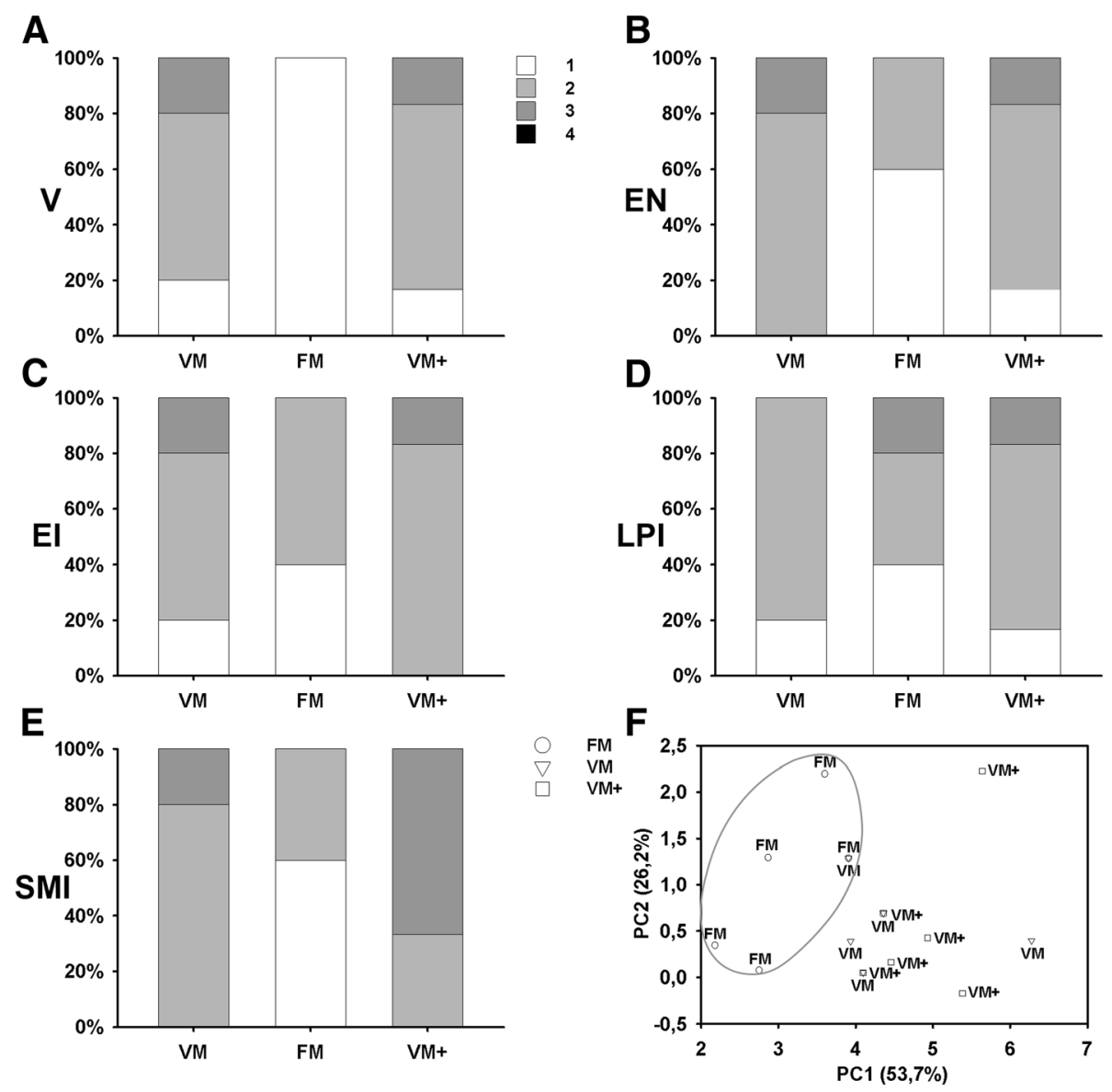

Fig. 4 Histological assessment of foregut sections of gilthead seabream fed different experimental diets, according to Fig. 1. Frequency bar charts showing differences in a supranuclear absorptive vacuolization $(V)$, b enterocytes nuclei (EN), c enterocytes infiltration (El), $\mathbf{d}$ lamina propria infiltration (LPI) and e submucosa infiltration (SMI). $\mathbf{f}$ Dispersion graph representing values of the first and second components for each foregut section assessed, obtained from the Principal component analysis of histological foregut scores according to diet. Only sections evaluated in all parameters were included in the Principal component analysis ( $n=5$ for VM and FM, $\mathrm{n}=6$ for VM+)

are able to maintain an active local immune system after the growth trial.

In contrast, this up-regulation is not observed in the VM group, which showed a lower expression of different pro-inflammatory markers and other genes related with the immune defence (igm, alp) and the regulation of epithelial permeability (ocl), even lower compared to the FM group. Occludin has been suggested as a key protein in the epithelial integrity maintenance and in the regulation of permeability and other properties of the epithelial barrier [49], being a marker of integrity of the tight junction between the enterocytes, and its underexpression could suggest deficiencies in the regulation of the gut inflammatory response $[16,20]$. Importance and physiologic function of alkaline phosphatase in digestion and a possible dietary regulation of its expression remain unclear, but it has been described as a gut mucosal defense factor, which seems to be implicated in the mucosal defence through the dephosphorylation of the lipopolysaccharides from the endotoxins of gram-negative bacteria [50]. Microbial lipopolysaccharides upregulates alp and its activity reduces toxicity of lipopolysaccharides [37], preventing from excessive inflammation in response to commensal microbes and helping to maintain the balance and integrity of the intestinal epithelial barrier [51].

The down-regulation of the expression of the genes could reflect that fish fed the VM diet were not triggering an inflammatory response at the end of the growth trial, as well as certain grade of immune mechanism suppression at local level, maybe evidencing an stress response. This depressed status could explain the higher mortality reported in this group and it could be linked with microbial imbalances that have been described in response to total fishmeal replacement in gilthead seabream [12].

In this sense, inclusion of great amounts of plant protein sources in aqua feeds for carnivorous species can be considered as a chronic stress factor, triggering a reponse by the host [52], which redirects more energy and resources 
to face with the stressor [53]. After long periods, immune mechanisms and other pathways that demand a continuous energy supply can be affected, leading to depressive or suppresive effects [52], leading to a chronic stress status. The suppresion of inflammatory and immune mechanisms in response to long term feeding high plant protein diets has been observed in previous research in different species [54, 55], including the gilthead seabream [9], and a differential response was also observed in different intestinal sections [22]..

Exposition to antinutrients included into the vegetablebased diets $(\mathrm{VM}+$, and specially, in $\mathrm{VM})$ throughout the growth assay could initially determine a prolongued inflammatory reaction in both experimental groups, demanding an additional energy expenditure that fish fed VM are not able tot sustain. Therefore, differences in the inflammatory and immune status of the gut between the $\mathrm{VM}$ and $\mathrm{VM}+$ group at the end of the growth assay might be explained by dietary composition. The VM diet only includes vegetable meals, and synthetic amino acids were added in order to comply minimum amino acid requirements [32], while in the VM+ diet squid and krill meal -which have higher quality protein than vegetable meals and could improve essential amino acid profile in terms of bioavailability- were included at 10\% and 5\% levels, respectively, and the amount of synthetic amino acids was lower. This inclusion of marine by-products at $15 \%$ level could favour the maintenance of an active gut proinflammatory response along the experiment, while the VM diet could be a deficient diet from a nutritional point of view and fish could be unable to meet the energy requirements to sustain the inflammatory response during all the growth trial. Chitin, which is present in the krill meal at $4 \%$, could increase the activity of the seabream immune system [56]. Composition in fiber, non-starch polysaccharides and fatty acids was very similar in both experimental diets and did not seem to be the reason of the observed differences.

The higher expression of pept 1 at the FG of fish confirms that this is the main production site and the intestinal section in which most of the absorption of small peptides takes place in gilthead seabream [36]. The downregulation of the peptide transporter in the anterior intestine of fish fed VM, and especially of fish fed $\mathrm{VM}+$, could be related to a greater presence of non-starch polysaccharides, saponins or other antinutrients in the vegetable based diets, which could alter the gut integrity and reduce the gastrointestinal passage of the food [57], and also to a lower digestibility of vegetable protein, which possibly contributes to a lower small peptide transport.

Finally, some possible minor inflammatory signs were observed at histological level in the present work in fish fed with both plant protein based diets (VM and $\mathrm{VM}+$ ), which could suggest that fish fed VM could develop an inflammatory reaction at certain point of the growth assay, before a possible suppression of inflammatory and immune mechanisms. Modifications include a higher grade of vacuolization in the epithelia and an increase of cell infiltration in the submucosa layer. Presence of supranuclear absorptive vacuoles in the epithelial layer is normal, but their excessive accumulation could be related to changes in the function of enterocytes [58], and it is often accompanied with evident signs of inflammation, as immune cell infiltration, as it has been observed in previous studies in response to different experimental diets in different species and in different segments of the gut $[4,7,59-62]$. Moreover, villi with a great number of GC were observed in the gut of fish fed diets containing vegetable meals, especially on the $\mathrm{VM}+$ group, which were not observed in the foregut of fish from the FM group., However, no statistical differences were determined, because villi with a reduced number of GC were observed in all experimental groups.. The increase in the number of GC has been noticed in rainbow trout [59], likewise in seabream fed with vegetable-based diet $[6,11]$, suggesting a possible alteration of secretory processes. GC secreted a mucus gel that covered the epithelium of the intestinal tract [63], so that the thicker mucus layer observed in fish fed vegetable based diets during the sampling process is consistent with these findings, although no differences were reported between experimental groups in the imuc expression in the HG, were it is constitutively expressed accordin to previous research [19]. However, no enteritis features in the FG were found, which is in accordance to previous studies [7]. In this sense, tolerance to antinutrients, which may be the cause of enteritis [59], seems to depend on species [4], and gilthead seabream seems to tolerate high levels of plant sources in diets without intestinal structural damage $[9,64]$, and only moderate changes, without pathological signs, have been observed in most research works $[4,7,9,25,43,44,64]$. In this sense, a higher degree of cellularity and the widening of the lamina propria -described as signs of inflammation- of fish fed vegetable diets, were not noticed in the present experiment, but similar observations were also made $[6,10,11]$ in feeding trials with high levels of fishmeal replacement, so this point must be clarified.

Finally, thinner villi observed in the FG of fish fed with VM can affect the nutrients absorption capacity, although impact on growth may be more related with the allocation of energy to face with an prolongued inflammatory status than with histomoprhological changes. However, a similar effect with great amounts of fishmeal replacement by plant sources has been observed [10] and further investigation should be also performed on this issue to explain that response. 


\section{Conclusion}

Total replacement of fishmeal by vegetable protein sources in diets for the on-growing of gilthead seabream had a negative impact on long-term fish survival under the experimental conditions, maybe caused by a lack of gut mucosal immune response derived from a lingering poor nutritional status. The inclusion of squid and krill meal in vegetable-based diets seemed to produce a long-term inflammation response in the gut, but no negative effects on fish survival were reported. However, development of vegetable-based diets that do not cause gut inflammatory reactions is needed in order to ensure, not only growth and survival, but also health status and welfare of fish.

\section{Additional files}

Additional file 1: Cq values reported in CDNA pooled samples when evaluating candidate reference genes. It Includes Cq determined for different candidate reference genes in six different cDNA pooled samples, and the average and standard desviation. (XLSX $9 \mathrm{~kb}$ )

Additional file 2: Relative gene expression of candidate target genes in cDNA pooled samples. A) Interleukine-1 $\beta$ (i/1 $\beta$ ), Interleukin-6 (i/6) and Interleukine-8 (il8); B) Tumor Necrosis Factor-a (tnfa), Caspase 1 (casp 1), Cyclooxigenase-2 (cox2); C) Mucin 2 (muc2), Mucin 2-like (muc2L), Mucin 13 (muc13); D) Intestinal Mucin (imuc), Mucin 18 (muc18), Immunoglobulin M (igm); E) Occludin (ocl) and Tubuline (tub); F) a-Amylase (aamy) and Alkaline Phosphatase (alp); G) Trypsin (tryp) and Peptide Transporter 1 (pept 1). Different genes are represented with different colours. Bars represent relative gene expression of CDNA pools (one per section and treatment), in the foregut ( $F G$ ) and the hindgut ( $\mathrm{HG}$ ). CDNA pool of the foregut of fish fed VM was used as a calibrator. (TIF $169 \mathrm{~kb}$ )

\begin{abstract}
Abbreviations
alp: Alkaline Phosphatase; ANOVA: Analysis of variance; casp 1: Caspase 1; cox2: Cyclooxygenase 2; CP: Crude protein; ECR: Economic Conversion Rate; ef1a: Elongation Factor 1a; El: Lymphocytic infiltration of the epithelilal layer; EPI: Economical Profit Index; FCR: Feed conversion ratio; FG: Foregut; FI: Feed intake; FM: Fishmeal-based diet; FW: Final weight; gapdh: Glyceraldehide 3phosphate dehydrogenase; GC: Goblet cells; HG: Hindgut;

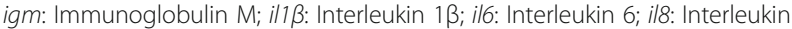
8; imuc: Intestinal Mucin; LP: Lamina propria thickness; LPI: Lymphocytic infiltration of the lamina propria; ML: Muscular layer; muc13: Mucin 13; muc19: Mucin 19; muc2: Mucin 2; muc2L: Mucin 2-like; N: Position of the nuclei of the enterocytes; ocl: Occludin; pept1: Peptide Transporter 1; rps18: Ribosomal protein S18; S: Survival; SEM: Standard error of the mean; SGR: Specific growth rate; SL: Serous layer; SMI: Lymphocytic infiltration of the submucosa; SML: Submucosa layer; tnfa: Tumor Necrosis Factor a; tryp: Trypsin; tub: Tubulin; V: Supranuclear vacuolization; VL: Villi length; VM + : Vegetable diet with marine ingredients; VM: Vegetable diet; VT: Villi thickness; aamy: a-Amylase; $\beta$ act: $\beta$-Actin
\end{abstract}

\section{Acknowledgements}

The first author was supported by a contract-grant (Contrato Pre-doctoral para la Formación de Profesorado Universitario) from Subprogramas de Formación y Movilidad within the Programa Estatal de Promoción del Talento y su Empleabilidad of the Ministerio de Educación, Cultura y Deporte of Spain.

\section{Funding}

The research has been partially funded by Vicerrectorat d'Investigació, Innovació i Transferència of the Universitat Politècnica de València, which belongs to the project Aquaculture feed without fishmeal (SP20120603). The funders had no role in study design, data collection and analysis, decision to publish or preparation of the manuscript.

\section{Availability of data and materials}

The datasets during the current study are available from the corresponding authors on reasonable request.

\section{Authors' contributions}

MJC, ATV, GPM and SML designed the assay. GE, MCC and RMO carried out the experiments. GE analysed the data. GE, DSP and SML did the manuscript and discussed the results. All authors read and approved the final manuscript.

\section{Ethics approval}

The experimental protocol was reviewed and approved by the Committee of Ethics and Animal Welfare of the Universitat Politècnica de València, following the Spanish Royal Decree 53/2013 and the European Directive 2010/63/UE on the protection of animals used for scientific purposes.

\section{Consent for publication}

Not applicable.

\section{Competing interests}

The authors declare that they have no competing interests.

\section{Publisher's Note}

Springer Nature remains neutral with regard to jurisdictional claims in published maps and institutional affiliations.

\section{Author details}

${ }^{1}$ Aquaculture and Biodiversity Research Group, Institute of Science and Animal Technology, (ICTA), Universitat Politècnica de València, Camino de Vera s/n, 46022 Valencia, Spain. ${ }^{2}$ Institute of Agrochemistry and Food Technology, Department of Biotechnology, Spanish National Research Council (IATA-CSIC), Av. Agustin Escardino 7, 46980 Paterna, Spain.

Received: 18 May 2018 Accepted: 25 September 2018

Published online: 03 October 2018

\section{References}

1. Hardy RW. Utilization of plant proteins in fish diets: effects of global demand and supplies of fishmeal. Aquac Res. 2010;41:770-6.

2. Martínez-Llorens S, Moñino AV, Vidal AT, Salvador VJM, Pla Torres M, Jover Cerdá $M$, et al. Soybean meal as a protein source in gilthead sea bream (Sparus aurata L.) diets: effects on growth and nutrient utilization. Aquac Res. 2007;38(1):82-90.

3. Tacon AGJ, Metian M. Global overview on the use of fish meal and fish oil in industrially compounded aquafeeds: trends and future prospects. Aquaculture. 2008;285:146-58.

4. Bonaldo A, Roem AJ, Fagioli P, Pecchini A, Cipollini I, Gatta PP. Influence of dietary levels of soybean meal on the performance and gut histology of gilthead sea bream (Sparus aurata L.) and European sea bass (Dicentrarchus labrax L.). Aquac Res. 2008:39(9):970-8.

5. Kissil G, Lupatsch I. Successful replacement of fishmeal by plant proteins in diets for the gilthead seabream, Sparus Aurata L. Isr J Aquac - Bamidgeh. 2004;56(3):188-99.

6. Monge-Ortíz R, Martínez-Llorens S, Márquez L, Moyano FJ, Jover-Cerdá M, Tomás-Vidal A. Potential use of high levels of vegetal proteins in diets for market-sized gilthead sea bream (Sparus aurata). Arch Anim Nutr. 2016; 70(2):155-72.

7. Santigosa E, Sánchez J, Médale F, Kaushik S, Pérez-Sánchez J, Gallardo MA. Modifications of digestive enzymes in trout (Oncorhynchus mykiss) and sea bream (Sparus aurata) in response to dietary fish meal replacement by plant protein sources. Aquaculture. 2008;282:68-74.

8. Santigosa E, García-Meilán I, Valentin JM, Pérez-Sánchez J, Médale F, Kaushik $\mathrm{S}$, et al. Modifications of intestinal nutrient absorption in response to dietary fish meal replacement by plant protein sources in sea bream (Sparus aurata) and rainbow trout (Onchorynchus mykiss). Aquaculture. 2011;317:146-54.

9. Sitjá-Bobadilla A, Peña-Llopis S, Gómez-Requeni P, Médale F, Kaushik S, Pérez-Sánchez J. Effect of fish meal replacement by plant protein sources on non-specific defence mechanisms and oxidative stress in gilthead sea bream (Sparus aurata). Aquaculture. 2005;249:387-400.

10. Martínez-Llorens S, Baeza-Ariño R, Nogales-Mérida S, Jover-Cerdá M, TomásVidal A. Carob seed germ meal as a partial substitute in gilthead sea bream 
(Sparus aurata) diets: amino acid retention, digestibility, gut and liver histology. Aquaculture. 2012;338-341:124-33.

11. Baeza-Ariño R, Martínez-Llorens S, Nogales-Mérida S, Jover-Cerda M, TomásVidal A. Study of liver and gut alterations in sea bream, Sparus aurata L., fed a mixture of vegetable protein concentrates. Aquac Res. 2014;47(2):460-71.

12. Estruch G, Collado MC, Peñaranda DS, Tomás Vidal A, Jover Cerdá M, Pérez Martínez G, et al. Impact of fishmeal replacement in diets for gilthead sea bream (Sparus aurata) on the gastrointestinal microbiota determined by pyrosequencing the 16S rRNA gene. PLoS One. 2015;10(8):e0136389. https:// doi.org/10.1371/journal.pone.0136389.

13. Fekete SG, Kellems RO. Interrelationship of feeding with immunity and parasitic infection: a review. Vet Med. 2007;52(4):131-43.

14. Kiron V. Fish immune system and its nutritional modulation for preventive health care. Anim Feed Sci Technol. 2012;173(1-2):111-33.

15. Minghetti M, Drieschner C, Bramaz N, Schug H, Schirmer K. A fish intestinal epithelial barrier model established from the rainbow trout (Oncorhynchus mykiss) cell line, RTgutGC. Cell Biol Toxicol. 2017;33:539-55.

16. Cerezuela R, Meseguer J, Esteban MÁ. Effects of dietary inulin, Bacillus subtilis and microalgae on intestinal gene expression in gilthead seabream (Sparus aurata L.). Fish Shellfish Immunol. 2013;34(3):843-8.

17. Couto A, Kortner TM, Penn M, Bakke AM, Krogdahl O-TA, et al. Effects of dietary soy saponins and phytosterols on gilthead sea bream (Sparus aurata) during the on-growing period. Anim Feed Sci Technol. 2014;198:203-14.

18. Estensoro I, Calduch-Giner JA, Kaushik S, Pérez-Sánchez J, Sitjá-Bobadilla A. Modulation of the IgM gene expression and IgM immunoreactive cell distribution by the nutritional background in gilthead sea bream (Sparus aurata) challenged with Enteromyxum leei (Myxozoa). Fish Shellfish Immunol. 2012;33(2):401-10.

19. Pérez-Sánchez J, Estensoro I, Redondo MJ, Calduch-Giner JA, Kaushik S, Sitjà-Bobadilla A. Mucins as diagnostic and prognostic biomarkers in a fish-parasite model: transcriptional and functional analysis. PLoS One. 2013;8(6):e65457.

20. Reyes-Becerril M, Guardiola F, Rojas M, Ascencio-Valle F, Esteban MÁ. Dietary administration of microalgae Navicula sp. affects immune status and gene expression of gilthead seabream (Sparus aurata). Fish Shellfish Immunol. 2013;35(3):883-9.

21. Pérez-Sánchez J, Benedito-Palos L, Estensoro I, Petropoulos Y, Calduch-Giner JA, Browdy CL, et al. Effects of dietary NEXT ENHANCE ${ }^{\circledR} 150$ on growth performance and expression of immune and intestinal integrity related genes in gilthead sea bream (Sparus aurata L.). Fish Shellfish Immunol. 2015;44:117-28.

22. Estensoro I, Ballester-Lozano G, Benedito-Palos L, Grammes F, Martos-Sitcha $J A$, Mydland L-T, et al. Dietary butyrate helps to restore the intestinal status of a marine teleost (Sparus aurata) fed extreme diets low in fish meal and fish oil. PLoS One. 2016;11(11):1-21.

23. Torrecillas S, Caballero MJ, Mompel D, Montero D, Zamorano MJ, Robaina L, et al. Disease resistance and response against Vibrio anguillarum intestinal infection in European seabass (Dicentrarchus labrax) fed low fish meal and fish oil diets. Fish Shellfish Immunol. 2017;67:302-11.

24. Schmittgen TD, Livak KJ. Analyzing real-time PCR data by the comparative $C$ T method. Nat Protoc. 2008;3(6):1101-8.

25. Omnes MH, Silva FCP, Moriceau J, Aguirre P, Kaushik S, Gatesoupe F-J. Influence of lupin and rapeseed meals on the integrity of digestive tract and organs in gilthead seabream (Sparus aurata L.) and goldfish (Carassius auratus L.) juveniles. Aquac Nutr. 2015;21:223-33.

26. Francis G, Makkar HPS, Becker K. Antinutritional factors present in plantderived alternate fish feed ingredients and their effects in fish. Aquaculture. 2001;199:197-227.

27. Gatlin DM III, Barrows FT, Brown P, Dabrowski K, Gaylord TG, Hardy RW, et al. Expanding the utilization of sustainable plant products in aquafeeds: a review. Aquac Res. 2007;38:551-79.

28. Kader MA, Bulbul M, Koshio S, Ishikawa M, Yokoyama S, Nguyen BT, et al. Effect of complete replacement of fishmeal by dehulled soybean meal with crude attractants supplementation in diets for red sea bream, Pagrus major. Aquaculture. 2012;350-353:109-16.

29. Gómez-Requeni P, Mingarro M, Calduch-Giner JA, Médale F, Martin SAM, Houlihan DF, et al. Protein growth performance, amino acid utilisation and somatotropic axis responsiveness to fish meal replacement by plant protein sources in gilthead sea bream (Sparus aurata). Aquaculture. 2004;232(1-4): 493-510.

30. Kader MA, Koshio S, Ishikawa M, Yokoyama S, Bulbul M. Supplemental effects of some crude ingredients in improving nutritive values of low fishmeal diets for red sea bream, Pagrus major. Aquaculture. 2010;308(3-4): $136-44$.

31. Mai K, Li H, Ai Q, Duan Q, Xu W, Zhang C, et al. Effects of dietary squid viscera meal on growth and cadmium accumulation in tissues of Japanese seabass, Lateolabrax japonicus (Cuvier 1828). Aquac Res. 2006;37(11):1063-9.

32. Peres $\mathrm{H}$, Oliva-Teles $\mathrm{A}$. The optimum dietary essential amino acid profile for gilthead seabream (Sparus aurata) juveniles. Aquaculture. 2009;296(1-2):81-6.

33. Cho CY, Slinger SJ, Bayley HS. Bioenergetics of salmonid fishes: energy intake, expenditure and productivity. Comp Biochem Physiol Part B. 1982; 73(1):25-41.

34. Venou B, Alexis MN, Fountoulaki E, Haralabous J. Effects of extrusion and inclusion level of soybean meal on diet digestibility, performance and nutrient utilization of gilthead sea bream ( Sparus aurata ). Aquaculture. 2006;261:343-56.

35. Pfaffl MW, Tichopad A, Prgomet C, Neuvians TP. Determination of stable housekeeping genes, differentially regulated target genes and sample integrity: BestKeeper-excel-based tool using pair-wise correlations. Biotechnol Lett. 2004;26:509-15.

36. Terova G, Robaina L, Izquierdo M, Cattaneo A, Molinari S, Bernardini G, et al. PepT1 mRNA expression levels in sea bream (Sparus aurata) fed different plant protein sources. Springerplus. 2013;2:17.

37. Bates JM, Akerlund J, Mittge E, Guillemin K. Intestinal alkaline phosphatase detoxifies lipopolysaccharide and prevents inflammation in zebrafish in response to the gut microbiota. Cell Host Microbe. 2007;2(6):371-82.

38. Adamidou S, Nengas I, Henry M, Grigorakis K, Rigos G, Nikolopoulou D, et al. Growth, feed utilization, health and organoleptic characteristics of European seabass (Dicentrarchus labrax) fed extruded diets including low and high levels of three different legumes. Aquaculture. 2009;293(3-4):263-71.

39. Daprà F, Gai F, Costanzo MT, Maricchiolo G, Micale V, Sicuro B, et al. Rice protein-concentrate meal as a potential dietary ingredient in practical diets for blackspot seabream Pagellus bogaraveo: a histological and enzymatic investigation. J Fish Biol. 2009;74(4):773-89.

40. Overland M, Sorensen M, Storebakken T, Penn M, Krogdahl A, Skrede A. Pea protein concentrate substituting fish meal or soybean meal in diets for Atlantic salmon (Salmo salar)-effect on growth performance, nutrient digestibility, carcass composition, gut health, and physical feed quality. Aquaculture. 2009;288(3-4):305-11.

41. Penn MH, Bendiksen EA, Campbell P, Krogdahl AS. High level of dietary pea protein concentrate induces enteropathy in Atlantic salmon (Salmo salar L.). Aquaculture. 2011;310(3-4):267-73.

42. Hedrera MI, Galdames JA, Jimenez-Reyes MF, Reyes AE, Avendaño-Herrera R, Romero J, et al. Soybean meal induces intestinal inflammation in zebrafish larvae. PLoS One. 2013;8(7):1-10.

43. Kokou F, Sarropoulou E, Cotou E, Rigos G, Henry M, Alexis M. Effects of fish meal replacement by a soybean protein on growth, histology, selected immune and oxidative status markers of Gilthead Sea bream, Sparus aurata. J World Aquac Soc. 2015;46(2):115-28.

44. Kokou F, Sarropoulou E, Cotou E, Kentouri M, Alexis M, Rigos G. Effects of graded dietary levels of soy protein concentrate supplemented with methionine and phosphate on the immune and antioxidant responses of gilthead sea bream (Sparus aurata L.). Fish Shellfish Immunol. 2017;64:111-21.

45. Calduch-Giner JA, Sitjà-Bobadilla A, Davey GC, Cairns MT, Kaushik S, PérezSánchez J. Dietary vegetable oils do not alter the intestine transcriptome of gilthead sea bream (Sparus aurata), but modulate the transcriptomic response to infection with Enteromyxum leei. BMC Genomics. 2012;13(1):470.

46. Piazzon MC, Galindo-Villegas J, Pereiro P, Estensoro I, Calduch-Giner JA, Gómez-Casado E, et al. Differential modulation of lgT and lgM upon parasitic, bacterial, viral, and dietary challenges in a perciform fish. Front Immunol. 2016;7. Article 637. https://doi.org/10.3389/fimmu.2016.00637.

47. Salinas I, Zhang Y, Sunyer JO. Mucosal immunoglobulins and B cells of teleost fish. Dev Comp Immunol. 2011;35(12):1346-65.

48. Krogdahl A, Bakke-McKellep AM, Roed KH, Baeverfjord G. Feeding Atlantic salmon Salmo salar L. soybean products: effects on disease resistance (furunculosis), and lysozyme and IgM levels in the intestinal mucosa. Aquac Nutr. 2000;6:77-84.

49. Chasiotis H, Effendi JC, Kelly SP. Occludin expression in goldfish held in ion-poor water. J Comp Physiol B Biochem Syst Environ Physiol. 2009; 179(2):145-54.

50. Chen KT, Malo MS, Beasley-Topliffe LK, Poelstra K, Millan JL, Mostafa G, et al. A role for intestinal alkaline phosphatase in the maintenance of local gut immunity. Dig Dis Sci. 2011;56(4):1020-7. 
51. Vaishnava S, Hooper LV. Alkaline phosphatase: keeping the peace at the gut epithelial surface. Cell Host Microbe. 2007;2(6):365-7.

52. Tort L. Stress and immune modulation in fish. Dev Comp Immunol [internet]. Elsevier Ltd. 2011;35(12):1366-75.

53. Martin SAM, Król E. Nutrigenomics and immune function in fish: new insights from omics technologies. Dev Comp Immunol. 2017;75:86-98.

54. Burrells C, Williams PD, Southgate PJ, Crampton VO. Immunological, physiological and pathological responses of rainbow trout (Oncorhynchus mykiss) to increasing dietary concentrations of soybean proteins. Vet Immunol Immunopathol. 1999;72:277-88.

55. Sahlmann C, Sutherland BJG, Kortner TM, Koop BF, Krogdahl Å, Bakke AM. Early response of gene expression in the distal intestine of Atlantic salmon (Salmo salar L.) during the development of soybean meal induced enteritis. Fish Shellfish Immunol. 2013;34(2):599-609.

56. Esteban MÁ, Cuesta A, Ortuño J, Meseguer J. Immunomodulatory effects of dietary intake of chitin on gilthead seabream ( Sparus aurata L.) innate immune system. Fish Shellfish Immunol. 2001;11:303-15.

57. Storebakken T, Kvien IS, Shearer KD, Grisdale-Helland B, Helland SJ. Estimation of gastrointestinal evacuation rate in Atlantic salmon (Salmo salar) using inert markers and collection of faeces by sieving: evacuation of diets with fish meal, soybean meal or bacterial meal. Aquaculture. 1999; 172(3-4):291-9.

58. Olsen RE, Myklebust R, Ringø E, Mayhew TM. The influences of dietary linseed oil and saturated fatty acids on caecal enterocytes in Arctic char (Salvelinus alpinus L.): a quantitative ultrastructural study. Fish Physiol Biochem. 2000;22(3):207-16.

59. Heikkinen J, Vielma J, Kemiläinen O, Tiirola M, Eskelinen P, Kiuru T, et al. Effects of soybean meal based diet on growth performance, gut histopathology and intestinal microbiota of juvenile rainbow trout (Oncorhynchus mykiss). Aquaculture. 2006;261 (1):259-68.

60. Krogdahl A, Bakke-McKellep AM, Baeverfjord G. Effects of graded levels of standard soybean meal on intestinal structure, mucosal enzyme activities, and pancreatic response in Atlantic salmon (Salmo salar L.). Aquac Nutr. 2003;9:361-71.

61. Cerezuela R, Fumanal M, Tapia-Paniagua ST, Meseguer J, Moriñigo MA Esteban MA. Changes in intestinal morphology and microbiota caused by dietary administration of inulin and Bacillus subtilis in gilthead sea bream (Sparus aurata L.) specimens. Fish Shellfish Immunol. 2013;34(5):1063-70.

62. Cerezuela R, Fumanal M, Tapia-Paniagua ST, Meseguer J, Moriñigo MÁ, Esteban MÁ. Histological alterations and microbial ecology of the intestine in gilthead seabream (Sparus aurata L.) fed dietary probiotics and microalgae. Cell Tissue Res. 2012;350(3):477-89.

63. Deplancke B, Gaskins HR. Microbial modulation of innate defense: goblet cells and the intestinal mucus layer. Am J Clin Nutr. 2001; 73(suppl):1131S-41S.

64. Kokou F, Rigos G, Henry M, Kentouri M, Alexis M. Growth performance, feed utilization and non-specific immune response of gilthead sea bream (Sparus aurata L.) fed graded levels of a bioprocessed soybean meal. Aquaculture. 2012;364-365:74-81.

Ready to submit your research? Choose BMC and benefit from:

- fast, convenient online submission

- thorough peer review by experienced researchers in your field

- rapid publication on acceptance

- support for research data, including large and complex data types

- gold Open Access which fosters wider collaboration and increased citations

- maximum visibility for your research: over $100 \mathrm{M}$ website views per year

At BMC, research is always in progress.

Learn more biomedcentral.com/submissions 